\title{
Purification and Properties of Trimethylamine $N$-Oxide Reductase from Shewanella sp. NCMB 400
}

\author{
By GRAHAM J. CLARKE† AND F. BRUCE WARD* \\ Department of Microbiology, University of Edinburgh, Edinburgh EH9 3JG, UK
}

(Received 22 July 1987 ; revised 7 September 1987)

\begin{abstract}
Two major trimethylamine- $N$-oxide reductases were detected in the periplasmic fraction of the marine bacterium Shewanella sp. NCMB 400 grown in the presence of trimethylamine $N$-oxide (TMAO). The high- $M_{\mathrm{r}}$ enzyme was purified to homogeneity and consisted of a single polypeptide of $M_{\mathrm{r}} 86000$ as judged by SDS-PAGE. The second enzyme had an $M_{\mathrm{r}}$ of 47000 . On isoelectric focusing, multiple forms of the purified enzyme were revealed with isoelectric points of $5 \cdot 1$ and $5 \cdot 2$. The $K_{\mathrm{m}}$ values for the $N$-oxides of trimethylamine, pyridine and $\gamma$-picoline were $0.02,2.41$ and $6.95 \mathrm{mM}$, respectively. The purified TMAO reductase is a molybdoenzyme containing $1.32 \mathrm{~mol} \mathrm{Mo} \mathrm{(mol} \mathrm{enzyme)})^{-1}$.
\end{abstract}

\section{INTRODUCTION}

In the absence of oxygen, many facultatively and obligately anaerobic bacteria can respire by using a variety of inorganic or organic terminal electron acceptors, including nitrate, nitrite, sulphate, sulphite and fumarate (Konings \& Michels, 1980). This process of anaerobic respiration is usually accompanied by changes in the components of the electron transport chain, particularly with respect to the appropriate terminal reductases (for reviews see Haddock \& Jones, 1977; Ingledew \& Poole, 1984).

Anaerobic respiration with trimethylamine $N$-oxide (TMAO) as terminal electron acceptor has been demonstrated in a number of bacteria, including members of the Enterobacteriaceae (Kim \& Chang, 1974; Yamamoto \& Ishimoto, 1977), Rhodopseudomonas spp. (Shultz \& Weaver, 1982; McEwan et al., 1983) and Shewanella spp. (Easter et al., 1983; Ringo et al., 1984). The components functioning in electron transport with TMAO in Escherichia coli and Salmonella typhimurium have been partially characterized and include specific dehydrogenases (Sakaguchi \& Kawai, 1977; Ishimoto \& Shimokawa, 1978), quinones (Cox \& Knight, 1981; Bragg \& Hackett, 1983), cytochromes $b$ and $c$ (Sakaguchi \& Kawai, 1978; Kwan \& Barrett, 1983a) and multiple TMAO reductase enzymes (Shimokawa \& Ishimoto, 1979; Kwan \& Barrett, 1983b). The latter are reported to be membrane bound and have been purified from $E$. coli (Shimokawa \& Ishimoto, 1979) and Salmonella typhimurium (Kwan \& Barrett, 1983b). TMAO reduction in the enterobacterial species appears unusual in that TMAO is not present in the natural habitat of these bacteria, TMAO being a low- $M_{\mathrm{r}}$ component of marine fish, comprising up to $7 \%$ of their dry weight (Groninger, 1959). Shewanella spp. are marine, pseudomonad-like bacteria that are associated with spoiling fish where they may account for up to $30 \%$ of the total bacterial population (Lee et al., 1977). The TMAO reductase in these bacteria appears to be either periplasmic (Easter et al., 1983) or loosely bound to the outer part of the cytoplasmic membrane

† Present address: Department of Microbiology, University of Birmingham, PO Box 363, Birmingham B15 2TT, UK.

Abbreviations: BV, benzyl viologen; DTNB, 5,5'-dithiobis-(2-nitrobenzoic acid); FAD, flavin adenine dinucleotide (oxidized form); FMN, flavin mononucleotide (oxidized form); LDAO, $N, N$-dimethyldodecylamine $N$-oxide; MV, methyl viologen; PMS, $N$-methylphenazonium methosulphate; PCMB, $p$-chloromercuribenzoate; TMAO, trimethylamine $N$-oxide. 
(Stenberg et al., 1984), depending upon the method of cell disruption. As part of an investigation on electron transport in alteromonads, we here report the purification of a periplasmic TMAO reductase from Shewanella sp. NCMB 400 and a comparison of its properties with those of other bacteria.

\section{METHODS}

Organism and growth. Shewanella sp. NCMB 400 (Lee et al., 1977) was cultured in the medium of Wood \& Baird (1943), containing $\left(\mathrm{g}^{-1}\right.$ ): $\mathrm{NaCl}, 20 ; \mathrm{K}_{2} \mathrm{HPO}_{4}, 1 ; \mathrm{MgSO}_{4} \cdot 7 \mathrm{H}_{2} \mathrm{O}, 1$; peptone (Oxoid), 5 ; yeast extract (Oxoid), 2 ; (pH 7.2). Aerobic cultures were obtained by inoculation of $500 \mathrm{ml}$ medium in a 2.51 flask with $10 \mathrm{ml}$ of an overnight starter culture and incubated for $4-6 \mathrm{~h}$ at $20^{\circ} \mathrm{C}$ in an orbital incubator $(120$ r.p.m.). Microaerobic conditions were obtained by diluting the aerobic culture into $21 \mathrm{fresh}$ medium containing TMAO (10 mM) in a 2.51 flask without stirring for $14-18 \mathrm{~h}$ at $20^{\circ} \mathrm{C}$. The alternative electron acceptors $\mathrm{KNO}_{3}(10 \mathrm{mM})$ and sodium fumarate $(10 \mathrm{mM})$ replaced TMAO in the growth medium when required.

Preparation of periplasm. Spheroplasts were prepared by the method of Birdsell \& Cota-Robles (1967) as modified by Easter et al. (1983). $\mathrm{MgSO}_{4}$ was omitted to prevent activity of proteases requiring divalent cations. The periplasm was separated from the spheroplast suspension by centrifugation at $35000 \mathrm{~g}$ for $30 \mathrm{~min}$ at $4{ }^{\circ} \mathrm{C}$.

$T M A O$ reductase assay. TMAO reductase activity was assayed by the method of Jones \& Garland (1977) as used by Easter $e t$ al. (1983) following the TMAO-dependent oxidation of reduced methyl viologen $\left(\mathrm{MV}^{+}\right)$at $600 \mathrm{~nm}$. Specific activity was expressed as nmol MV ${ }^{+}$oxidized $\min ^{-1}(\mathrm{mg} \text { protein })^{-1}(\mathrm{U})$. Samples were assayed in TMAO reductase buffer composed of $0.1 \mathrm{M}-\mathrm{KH}_{2} \mathrm{PO}_{4}, \mathrm{pH} 6.5$, containing $0.1 \mathrm{M}-\mathrm{NaCl}$ and $1 \mathrm{mM}-\mathrm{MgSO}_{4} \cdot 7 \mathrm{H}_{2} \mathrm{O}$. For inhibition studies with $\mathrm{Na}_{2} \mathrm{MoO}_{4} \cdot 2 \mathrm{H}_{2} \mathrm{O}$, MacLeod buffer B (Martin \& MacLeod, 1971), containing $50 \mathrm{mM}$ Tris $/ \mathrm{HCl}(\mathrm{pH} 7.0), 300 \mathrm{~mm}-\mathrm{NaCl}, 50 \mathrm{mM}-\mathrm{MgSO}_{4}$ and $10 \mathrm{mM}-\mathrm{KCl}$, was used to prevent autooxidation of TMAO reductase buffer.

Purification of TMAO reductase. All procedures were done at $4{ }^{\circ} \mathrm{C}$. The periplasm obtained from a 7.51 culture grown microaerobically in the presence of TMAO was fractionated by precipitation for $2 \mathrm{~h}$ with a saturated solution of $\left(\mathrm{NH}_{4}\right)_{2} \mathrm{SO}_{4}, \mathrm{pH} \mathrm{7.2}$, followed by centrifugation at $30000 \mathrm{~g}$ for $30 \mathrm{~min}$. The precipitate obtained between $60-80 \%$ saturation was resuspended in ion-exchange buffer, containing $50 \mathrm{~mm}$-Tris/ $/ \mathrm{HCl}, \mathrm{pH} 7.0$ (about $36 \mathrm{ml}$ ), and dialysed against the same buffer for $16 \mathrm{~h}$. The dialysed fraction was applied to a column of DEAESepharose CL 6B ( $2.5 \times 10 \mathrm{~cm}$, Pharmacia) equilibrated with ion-exchange buffer. The column was washed with two volumes of the same buffer and bound protein was eluted with a $300 \mathrm{ml}$ linear gradient of $0-0.3 \mathrm{M}-\mathrm{NaCl}$ in the same buffer (flow rate, $12 \mathrm{ml} \mathrm{h}^{-1}$; fraction volume, $7.5 \mathrm{ml}$ ). The major peak of activity eluting at $0.1 \mathrm{M}-\mathrm{NaCl}$ was pooled (about $36 \mathrm{ml}$ ) and dialysed for $16 \mathrm{~h}$ against $10 \mathrm{mM}-\mathrm{K}_{2} \mathrm{HPO}_{4}, \mathrm{pH} 7 \cdot 2$. The pooled fraction was applied to an hydroxyapatite column $(2.6 \times 15 \mathrm{~cm})$ and washed with two column volumes of the same buffer. Bound protein was eluted with a $300 \mathrm{ml}$ linear gradient of $10-500 \mathrm{mM}-\mathrm{K}_{2} \mathrm{HPO}_{4}, \mathrm{pH} 7.2$ (flow rate, $12 \mathrm{ml} \mathrm{h}^{-1}$; fraction volume, $7.5 \mathrm{ml}$ ). Active fractions were pooled and concentrated by ultrafiltration (Amicon 8010 stirred cell and PM 10 membrane filter). The pooled and concentrated material $(<10 \mathrm{ml})$ was applied to a column of Sephacryl S-300 $(1.6 \times 100 \mathrm{~cm}$, Pharmacia) and eluted with $10 \mathrm{mM}$-Tris/ $\mathrm{HCl}, \mathrm{pH} 7 \cdot 2$, containing $0.2 \mathrm{M}-\mathrm{NaCl}$ (flow rate, $8 \mathrm{ml} \mathrm{h}^{-1}$; fraction volume, $3 \mathrm{ml}$ ). The active fractions were pooled, concentrated by ultrafiltration and stored at $-20^{\circ} \mathrm{C}$.

$P A G E$. This was done according to Laemmli (1970), using gel slabs ( $1 \mathrm{~mm}$ thickness; $12 \%$, w/v, acrylamide) prepared in the presence or absence of SDS $(1 \%, w / v)$. For $M_{\mathrm{r}}$ determinations, samples were prepared in the presence of $\operatorname{SDS}(2 \%, \mathrm{w} / \mathrm{v})$; reducing conditions were provided by incubation with $5 \mathrm{mM}-\mathrm{DTT}$ at $100^{\circ} \mathrm{C}$ for $5 \mathrm{~min}$. Standard proteins were prepared in a similar manner and included $\beta$-galactosidase $\left(M_{\mathrm{r}} 114000\right)$, phosphorylase $b$ (92000), ovalbumin (43000), lysozyme (14000) and horse-heart cytochrome $c(12500)$. Gels were stained for protein either with Coomassie blue R250 or the silver-stain method of Merrill et al. (1981). A TMAO reductase activity stain was done on samples electrophoresed in the presence or absence of SDS but without DTT incubation at $100^{\circ} \mathrm{C}$. Gels were stained according to Shimokawa \& Ishimoto (1979) in $50 \mathrm{~mm}-\mathrm{Tris} / \mathrm{HCl}, \mathrm{pH} \mathrm{7.4}$, containing 40 mM-TMAO, $7.5 \mathrm{~mm}-\mathrm{KHCO}_{3}, 2 \mathrm{~mm}-\mathrm{MV}^{++}$, and $5 \mathrm{mM}$-sodium dithionite added just prior to use. Gels were incubated for 5-10 $\mathrm{min}$ at room temperature until zones of decolourization associated with enzyme activity were observed against the blue background of the gel. The stained gel was either photographed directly or fixed using 2,3,5-triphenyltetrazolium chloride $(2.5 \%, \mathrm{w} / \mathrm{v})$. In some experiments the method was modified by using $100 \mathrm{mM}-$ Tris/ $\mathrm{HCl} 100 \mathrm{mM}-\mathrm{KH}_{2} \mathrm{PO}_{4}, \mathrm{pH} 7 \cdot 8$, instead of $50 \mathrm{mM}-\mathrm{Tris} / \mathrm{HCl}, \mathrm{pH} 7 \cdot 4$, and adding sodium dithionite as a concentrated solution made up in $100 \mathrm{mM}-\mathrm{Tris} / \mathrm{HCl}$ adjusted to $\mathrm{pH} 8.0$.

Analytical gel filtration. The $M_{\mathrm{r}}$ of TMAO reductase was estimated by gel filtration on Sephacryl S-300 $(1.5 \times$ $100 \mathrm{~cm}$ ) equilibrated in $10 \mathrm{mM}$-Tris $/ \mathrm{HCl}, \mathrm{pH} 7 \cdot 2$, containing $0.2 \mathrm{M}-\mathrm{NaCl}$. Calibration of the column was achieved using the standard proteins thyroglobulin (669 000), BSA (67000), chymotrypsinogen A (25000) and horse-heart cytochrome $c$ (12500).

Determination of the isoelectric point. Flat-bed isoelectric focusing was done on an LKB Ultraphor with prepared isoelectric focusing polyacrylamide gels of $\mathrm{pH}$ gradient 3.5-9.5 (LKB). Samples of enzyme were dialysed against $10 \mathrm{mM}-\mathrm{Tris} / \mathrm{HCl}, \mathrm{pH} 7 \cdot 2$, prior to electrophoresis to remove $\mathrm{NaCl}$. Following electrophoresis, the gel was 
sectioned; the position of TMAO reductase was determined by the enzyme activity stain described for PAGE and the $\mathrm{pH}$ gradient was determined by sectioning part of the electrofocusing gel in $0.5 \mathrm{~mm}$ increments, each piece being placed into a separate tube containing $1 \mathrm{ml}$ degassed $\mathrm{NaCl}(0.5 \%, \mathrm{w} / \mathrm{v})$, with the $\mathrm{pH}$ of each being recorded after $16 \mathrm{~h}$

Other assays. Protease activity in samples of periplasm was determined by the neutral protease assay of Levy $e t$ al. (1976) and by the clearing of opacity in $1 \%(\mathrm{w} / \mathrm{v})$ casein $/ 1 \%(\mathrm{w} / \mathrm{v})$ agar plates (Oxoid) after incubation for $1-7 \mathrm{~d}$ at $4{ }^{\circ} \mathrm{C}$. Non-haem iron was determined by the method of Doeg \& Ziegler (1962) as described by Brumby \& Massey (1967) using water-soluble bathophenanthroline sulphonate. Molybdenum was determined by atomic absorption spectroscopy using a Varian AA 1475 model with GTA 95 graphite tube atomizer. Absorption spectrophotometry was done using a Pye Unicam SP 1800 recording spectrophotometer with samples containing approximately $1 \mathrm{mg}$ protein $\mathrm{ml}^{-1}$ and a path length of $1 \mathrm{~cm}$. Samples were oxidized in the presence of air and reduced with sodium dithionite. Protein was estimated by the method of Peterson (1977).

Chemicals. All chemicals were obtained from Sigma or BDH unless otherwise stated. $N, N$-Dimethyldodecylamine $N$-oxide (LDAO) was obtained from Ceca.

\section{RESULTS}

\section{Multiple TMAO reductase enzymes}

Periplasm $\left(1.56 \mathrm{mg} \mathrm{ml}^{-1}\right)$ from cells grown microaerobically in the presence of TMAO was analysed by PAGE and SDS-PAGE to determine the multiplicity of TMAO reductase enzymes. Activity staining by the normal method revealed two enzymes after both PAGE and SDSPAGE, designated high- $M_{\mathrm{r}}$ and low- $M_{\mathrm{r}}$ TMAO reductase by their relative mobility. When the high- $M_{\mathrm{r}}$ activity was excised after PAGE and re-electrophoresed in the presence of SDS, the activity migrated as a single band in the high- $M_{\mathrm{r}}$ position indicating that there is no common monomer for the two enzymes. No protease activity was detected in the periplasm.

Using the modified procedure at normal loadings the same two bands were seen on SDSPAGE gels (Fig. 1, track 1). At low loadings (track 2) only the low- $M_{\mathrm{r}}$ band was seen due to partial inactivation of the high- $M_{\mathrm{r}}$ enzyme in the presence of SDS. This was confirmed by running native PAGE gels at the same loading; the high- $M_{\mathrm{r}}$ band was then much more prominent (tracks 3 and 6 ). At higher loadings a further minor band was observed beyond the low- $M_{\mathrm{r}}$ band (track 3 ).

\section{Induction of TMAO reductase}

The periplasmic fractions from cells cultured under various growth conditions were analysed by PAGE and activity staining to determine the relative induction pattern of the two TMAO reductases. PAGE and SDS-PAGE gels were run using periplasm from cells grown either in the presence or the absence of TMAO, DMSO, nitrate or fumarate as electron acceptors. Periplasm isolated from cells grown with TMAO or DMSO showed a single high- $M_{\mathrm{r}}$ band on PAGE gels (track 6) but corresponding tracks from cells grown with nitrate, fumarate or without any added electron acceptor gave either faint bands or none at all using the normal staining method (track 7). Similar results were obtained with SDS gels. However, using the modified staining method the difference between results obtained for cells grown in the presence of TMAO or DMSO and those grown with nitrate, fumarate or without added electron acceptor was more apparent. The higher contrast obtained with this modified staining method enabled better resolution and the visualization of further faint bands on SDS-PAGE gels. The faint staining in the region corresponding to the high- $M_{\mathrm{r}}$ TMAO reductase band was due to multiple bands (tracks 4 and 5). In addition a number of bands of very high mobility corresponding to proteins with $M_{\mathrm{r}}$ values of about $12000-20000$ were observed.

The low- $M_{\mathrm{r}}$ band was observed in gels of the periplasmic fraction of all cells irrespective of the exogenous electron acceptor (Fig. 1). With the modified procedure further minor bands were observed on SDS-PAGE gels for cells grown on nitrate, fumarate or without added electron acceptor, located close to the main low- $M_{\mathrm{r}}$ band. Only one of these was observed with periplasm from cells grown in the presence of TMAO or DMSO. On the corresponding native gels the main low- $M_{\mathrm{r}}$ enzyme stained less well; it was detected usually as a single band but occasionally as a doublet with extracts from cells grown with fumarate, nitrate or without added electron acceptor. 


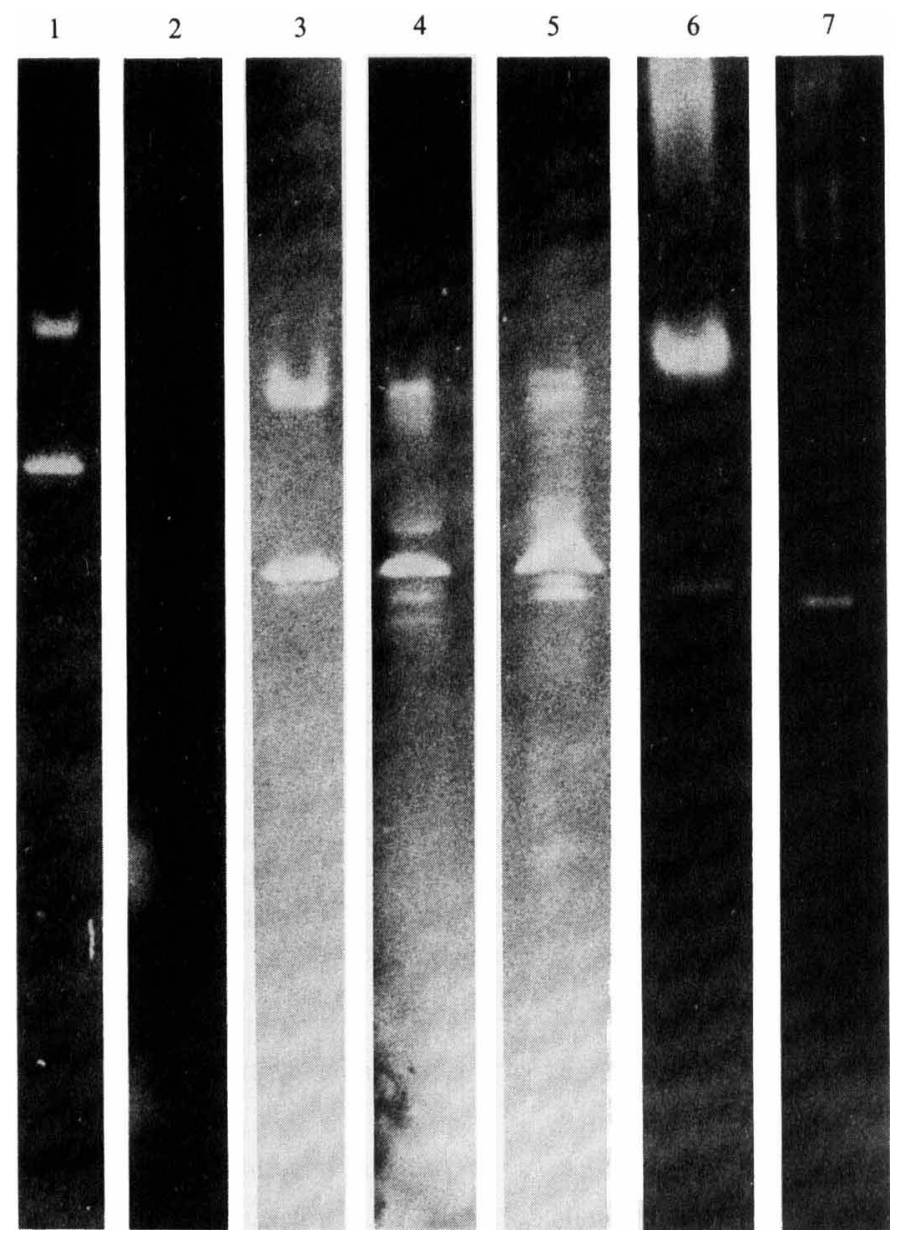

Fig. 1. Zones of TMAO reductase activity on PAGE and SDS-PAGE gels. The figure is composed from three gels using the same batch of periplasms from cells grown with various electron acceptors $(10 \mathrm{mM})$. Gel type, electron acceptor in growth medium and loading of protein $(\mu \mathrm{g})$ and TMAO reductase activity (U) were as follows for each track: (1) SDS gel 1, TMAO, 0.18, 4; (2) SDS gel 1, TMAO, 0.01, 0.26; (3) SDS gel 2, TMAO, 0.7, 17; (4) SDS gel 2, nitrate, 25, 13; (5) SDS gel, none, 71, 25; (6) native gel, TMAO, $0 \cdot 7,17$; (7) native gel, fumarate, 9, 13.

\section{Purification of TMAO reductase}

The high- $M_{\mathrm{r}}$ TMAO reductase was purified from the periplasm of cells grown microaerobically in the presence of TMAO as detailed under Methods. A summary of the purification scheme is given in Table 1. Separation of the high- $M_{\mathrm{r}}$ enzyme from the low- $M_{\mathrm{r}}$ enzyme occurred during $\left(\mathrm{NH}_{4}\right)_{2} \mathrm{SO}_{4}$ precipitation. The purified enzyme was judged to be homogeneous by the presence of a single band of protein coincident with a single band of enzyme activity.

The $M_{\mathrm{r}}$ and isoelectric point of TMAO reductase

The native $M_{\mathrm{r}}$ of the purified enzyme was estimated by analytical gel filtration on Sephacryl S-300 to be 84000 . This was confirmed by SDS-PAGE under reducing conditions, which indicated an $M_{\mathrm{r}}$ of 86000 ; there was no detectable dissociation of the protein into subunits. The low- $M_{\mathrm{r}}$ TMAO reductase was estimated to have an $M_{\mathrm{r}}$ of 47000 by SDS-PAGE in the absence of reducing conditions by activating staining with a gel run under the same conditions.

Electrofocusing of the purified enzyme gave two zones of activity corresponding to $\mathrm{pH} 5 \cdot 1$ and $5 \cdot 2$ whereas unfractioned periplasm gave bands of activity at $\mathrm{pH} 4.4,4.9$ and $5 \cdot 2$. 
Table 1. Purification scheme for TMAO reductase

\begin{tabular}{|c|c|c|c|c|c|c|}
\hline Sample & $\begin{array}{c}\text { Protein } \\
\left(\mathrm{mg} \mathrm{ml}^{-1}\right)\end{array}$ & $\begin{array}{c}\text { Specific } \\
\text { activity } \\
\text { (U) }\end{array}$ & $\begin{array}{l}\text { Purification } \\
\text { (-fold) }\end{array}$ & $\begin{array}{l}\text { Total } \\
\text { protein } \\
\text { (mg) }\end{array}$ & $\begin{array}{l}\text { Total } \\
\text { activity } \\
\text { (U) }\end{array}$ & $\begin{array}{l}\text { Yield* } \\
(\%)\end{array}$ \\
\hline Periplasm & 1.91 & 3846 & $1 \cdot 0$ & $343 \cdot 38$ & 1320639 & 100 \\
\hline$\left(\mathrm{NH}_{4}\right)_{2} \mathrm{SO}_{4}(60-80 \%)$ & $1 \cdot 36$ & 10671 & 3.7 & 48.96 & 522452 & $30 \cdot 5$ \\
\hline Ion exchange & $0 \cdot 13$ & 72525 & $16 \cdot 8$ & 4.68 & 339417 & $18 \cdot 0$ \\
\hline Hydroxyapatite & $0 \cdot 13$ & 121591 & $34 \cdot 5$ & 0.92 & 112257 & 7.9 \\
\hline Gel filtration & $0 \cdot 44$ & 211530 & $55 \cdot 0$ & 0.44 & 92447 & 6.9 \\
\hline
\end{tabular}

\section{Electron donors to TMAO reductase}

Periplasmic and purified TMAO reductase were analysed for their ability to oxidize a variety of potential electron donors. Only reduced benzyl viologen $\left(\mathrm{BV}^{+}\right)$was effective, giving approximately $50 \%$ and $60 \%$ of the activity measured with $\mathrm{MV}^{++}$in periplasmic and purified enzyme fractions, respectively. No activity was measured with $\mathrm{FADH}_{2}, \mathrm{NADH}, \mathrm{NADPH}$ and the reduced forms of methylene blue and $N$-methylphenazonium methosulphate (PMS).

\section{Electron acceptors for TMAO reductase}

Compounds possessing oxide and/or multiple alkyl moieties together with known electron acceptors from other respiratory systems were analysed for their ability to act as alternative electron acceptors to TMAO with periplasmic and purified TMAO reductase. Specific activities were expressed as a percentage of that obtained using TMAO as acceptor. LDAO gave the highest activity with the periplasmic and purified enzyme sources (63\% and $41 \%$, respectively). Adenosine $\mathrm{N}$-oxide gave $40 \%$ and $35 \%$, hydroxylamine $\mathrm{N}$-oxide gave $19 \%$ and $3 \%$, and $\gamma$ picoline $\mathrm{N}$-oxide gave $11 \%$ and $12 \%$ with the two respective enzyme sources. Little or no activity was detected with $\mathrm{KNO}_{3}$, sodium fumarate, DMSO, $\mathrm{NaClO}_{3}$, betaine, carnitine, pyridine $\mathrm{N}$ oxide or nicotinamide $\mathrm{N}$-oxide.

The $K_{\mathrm{m}}$ values for TMAO, LDAO and $\gamma$-picoline $N$-oxide were determined by LineweaverBurk plots at $0.02,2.41$ and $6.92 \mathrm{mM}$, respectively.

\section{Inhibitors of TMAO reductase}

The effects of various metal ions and potential inhibitors were examined by preincubation of samples of periplasm or purified enzyme with each compound for $5 \mathrm{~min}$ (Table 2). Molybdate was assayed in MacLeod buffer $\mathrm{B}$. The effect of $\mathrm{Cu}^{2+}, \mathrm{Fe}^{2+}$ and $\mathrm{Fe}^{3+}$ could not be measured because these ions oxidized $\mathrm{MV}^{\cdot+}$ and $\mathrm{BV}^{++}$in both TMAO reductase buffer and MacLeod buffer $\mathrm{B}$. The reduction of TMAO was inhibited by high concentrations of molybdate and tungstate. Both 5,5'-dithiobis-(2-nitrobenzoic acid) (DTNB) and p-chloromercuribenzoate (PCMB) inhibited activity; inhibition by PCMB was relieved by incubation with DTT, suggesting the involvement of thiol group(s) in catalysis. Iodoacetate, sodium chlorate and $\mathrm{KCN}$ gave only partial inhibition. Little inhibition was obtained with the metal-chelating compounds 1,10-phenanthroline or 2,2'-dipyridyl.

\section{Other properties}

Activity was not stimulated in the presence of FAD or FMN. Molybdenum was present in the purified enzyme at $1.3 \mathrm{~mol}(\mathrm{~mol} \text { enzyme })^{-1}$, but iron was not detected.

\section{DISCUSSION}

The reduction of TMAO in Shewanella spp. has been shown to be a respiration-linked process on the basis of growth-yield studies (Easter et al., 1982) and by the demonstration of a collapsible membrane potential generated in the presence of TMAO (Stenberg et al., 1984). Two major 
Table 2. Inhibitors of TMAO reductase

Metal ions were added as their chloride salts at the concentration indicated.

\begin{tabular}{|c|c|c|c|}
\hline \multirow[b]{2}{*}{ Inhibitor } & \multirow{2}{*}{$\begin{array}{l}\text { Concn } \\
\text { (mM) }\end{array}$} & \multicolumn{2}{|c|}{ Specific activity* $(\%)$} \\
\hline & & Periplasm & Pure enzyme \\
\hline None & - & 100 & 100 \\
\hline $\mathrm{Ca}^{2+}$ & 1 & 97 & 78 \\
\hline $\mathrm{Mn}^{2+}$ & 1 & 100 & 78 \\
\hline $\mathrm{Na}_{2} \mathrm{WO}_{4}$ & 1 & 93 & 36 \\
\hline \multirow[t]{2}{*}{$\mathrm{Na}_{2} \mathrm{MoO}_{4}$} & 1 & 39 & 28 \\
\hline & $0 \cdot 1$ & 63 & 59 \\
\hline $\mathrm{NaN}_{3}$ & $5 \cdot 0$ & 67 & 91 \\
\hline \multirow[t]{2}{*}{$\mathrm{KCN}$} & $5 \cdot 0$ & 62 & 69 \\
\hline & $1 \cdot 0$ & 88 & 98 \\
\hline KSCN & $5 \cdot 0$ & 101 & 91 \\
\hline 1,10-Phenanthroline & $1 \cdot 0$ & 97 & 84 \\
\hline 2,2-Dipyridyl & $2 \cdot 5$ & 96 & 85 \\
\hline $\mathrm{NaClO}_{3}$ & $5 \cdot 0$ & 67 & 91 \\
\hline \multirow[t]{2}{*}{ Iodoacetate } & $5 \cdot 0$ & 53 & 76 \\
\hline & $1 \cdot 0$ & 90 & 100 \\
\hline DTNB & 1.0 & 15 & 33 \\
\hline DTNB $+1 \mathrm{mM}-\mathrm{DTT}$ & $1 \cdot 0$ & 26 & 35 \\
\hline PCMB & $0 \cdot 3$ & 12 & 10 \\
\hline PCMB + $1 \mathrm{mM}$-DTT & $0 \cdot 3$ & 87 & 93 \\
\hline DTT & $1 \cdot 0$ & 103 & 100 \\
\hline
\end{tabular}

* Specific activities of TMAO reductase for the periplasm and purified enzyme without inhibitor (i.e. $100 \%$ values) were 8328 and $113730 \mathrm{U}^{\text {(mg protein) }}{ }^{-1}$, respectively.

TMAO reductase activities were detected in periplasm from cells of Shewanella putrefaciens grown in the presence of TMAO. The periplasmic nature of these enzymes was consistent with previous data on their cellular location and function (Easter et al., 1983). The multiplicity of enzymes appears to be a common feature of TMAO reduction in that cultures of both E. coli and Salmonella typhimurium, induced for TMAO reductase synthesis, contain four TMAO-reducing enzymes (Shimokawa \& Ishimoto, 1979; Kwan \& Barrett, 1983a,b). The two major enzymes from Shewanella sp. NCMB 400 could be partially resolved on the basis of their regulation. The high- $M_{\mathrm{r}}$ enzyme was induced by TMAO and DMSO and was absent or present at only low levels in cells grown on fumarate or nitrate. This was shown by zymogram staining and is supported by the high specific activities measured. By contrast the low- $M_{\mathrm{r}}$ enzyme appeared to be constitutively synthesized under microaerobic conditions, the activity being independent of the electron acceptor present. The high- and low- $M_{\mathrm{r}}$ enzymes differed in their sensitivity to inactivation by SDS, the low- $M_{\mathrm{r}}$ enzyme being more resistant. A similar distribution of enzymes was observed in $E$. coli with three inducible forms and one constitutive form of the reductase (Shimokawa \& Ishimoto, 1979), and in Salmonella typhimurium with two inducible forms and one constitutive form (K wan \& Barrett, 1983a). The origin of the multiple faint bands observed in gels using periplasm from cells grown with nitrate, fumarate or without added electron acceptor is not known. They may be either precursors or degradation products of the high- and low- $M_{\mathrm{r}}$ TMAO reductases. The absence of periplasmic protease activity is evidence against them being degradation products and the simpler pattern of staining observed with extracts from TMAO- and DMSO-grown cells is consistent with them being precursors. However there are alternative plausible explanations. It should be emphasized that using equivalent protein loadings rather than equal activity loadings (as shown here) these minor bands cannot be seen.

The inducible high- $M_{\mathrm{r}}$ enzyme was purified to homogeneity with an approximate 56-fold increase in purity and a $7 \%$ recovery. The $60 \%$ loss in activity following $\left(\mathrm{NH}_{4}\right)_{2} \mathrm{SO}_{4}$ fractionation was most probably due to the resolution between the two TMAO reductase enzymes that occurred during this step, the low- $M_{\mathrm{r}}$ TMAO reductase precipitating between 40 
$60 \%$ saturation (not shown). The loss in yield after hydroxyapatite was surprising as most of the eluted protein was recovered, suggestive of some denaturation during this stage.

The estimated $M_{\mathrm{r}}$ of 86000 differs from the values obtained for the major inducible amine oxide reductases of $E$. coli $\left(M_{\mathrm{r}} 220000\right)$ and Salmonella typhimurium $\left(M_{\mathrm{r}} 332000\right)$ (Shimokawa \& Ishimoto, 1979; Kwan \& Barrett, 1983b), with no evidence of aggregation into oligomeric activities (Kwan \& Barrett, 1983b). In addition, the purified enzyme from Shewanella sp. NCMB 400 was not dissociated into subunits unlike the enzymes of E. coli and Salmonella typhimurium. The purified enzyme gave rise to two activities after isoelectric focusing, possibly indicating two ionic species of the same $M_{\mathrm{r}}$ protein.

The purified enzyme reduced a restricted range of alternative electron acceptors, particularly in comparison with the range of electron acceptors reduced by the $E$. coli enzyme, also termed a tertiary amine $N$-oxide, reductase EC 1.7.99 (Shimokawa \& Ishimoto, 1979). In this respect, the enzyme from Shewanella sp. NCMB 400 is best described as a TMAO reductase. Although the purified enzyme was unable to reduce DMSO, this compound was shown to be an effective inducer of the enzyme in culture, indicating a gratuitous type of induction. Molybdenum was shown to be present in the purified enzyme, in agreement with molybdenum cofactor complementation studies indicating the presence of the molybdenum cofactor (Nasser \& Ward, 1983). The molybdenum may be assumed to be tightly associated with the enzyme due to the lack of both inactivation by SDS during SDS-PAGE and by molybdenum-chelating agents such as KSCN (Lam \& Nicholas, 1969).

We thank the Science and Engineering Research Council for the award of a research studentship to G.J.C.

\section{REFERENCES}

Birdsell, D. C. \& Cota-Robles, E. H. (1967) Production and ultrastructure of lysozyme and EDTA-lysozyme spheroplasts of Escherichia coli. Journal of Bacteriology 93, 427-437.

BRAGG, P. D. \& HACKeTt, N. R. (1983). Cytochromes of the trimethylamine $N$-oxide anaerobic respiratory pathway of Escherichia coli. Biochimica et biophysica acta 725, 168-177.

BRUMBY, P. E. \& MASSEY, V. (1967). Determination of nonhaem iron, total iron and copper. Methods in Enzymology 10, 463-474.

Cox, J. C. \& KNIGHT, R. (1981). Trimethylamine $N$ oxide (TMAO) reductase activity in chlorate-resistant or respiration-deficient mutants of Escherichia coli. FEMS Microbiology Letters 12, 249-252.

DOEG, K. A. \& Ziegler, D. M. (1962). Simplified method for the estimation of iron in mitochondria and submitochondrial fractions. Archives of Biochemistry and Biophysics 97, 37-40.

EAster, M. C., Gibson, D. M. \& WARD, F. B. (1982). A conductance method for the assay and study of bacterial trimethylamine oxide reduction. Journal of Applied Bacteriology 52, 357-365.

Easter, M. C., Gibson, D. M. \& Ward, F. B. (1983). The induction and location of trimethylamine $\mathrm{N}$ oxide reductase in Shewanella sp. NCMB 400. Journal of General Microbiology 129, 3689-3696

GroNINGER, H. S. (1959). Occurrence and significance of trimethylamine oxide in marine animals. Special Scientific Report Fisheries, no. 333, pp. 1-22. Washington, DC: US Fish and Wildlife Service.

HADDOCK, B. A. \& JonES, C. W. (1977). Bacterial respiration. Bacteriological Reviews 41, 47-99.

Ingledew, W. J. \& Poole, R. K. (1984). The respiratory chains of Escherichia coli. Microbiological Reviews 48, 222-271.
Ishimoto, M. \& Shimokawa, O. (1978). Reduction of trimethylamine $\mathrm{N}$-oxide by Escherichia coli as anaerobic respiration. Zeitschrift für allgemeine Mikrobiologie 18, 173-181.

Jones, R. W. \& Garland, P. B. (1977). Sites and specificity of the reaction of bipyridylium compounds with anaerobic respiratory enzymes of Escherichia coli. Effects of permeability barriers imposed by the cytoplasmic membrane. Biochemical Journal 164, 199-211

KIM, K. E. \& ChanG, G. W. (1974). Trimethylamine oxide reduction by Salmonella. Canadian Journal of Microbiology 20, 1745-1748.

Konings, W. N. \& Michels, P. A. M. (1980). Electrontransfer-driven solute translocation across bacterial membranes. In Diversity of Bacterial Respiratory Systems, vol. 1, pp. 33-86. Edited by C. J. Knowles. Boca Raton, Fla: CRC Press.

KWAN, H. S. \& BARReTT, E. L. (1983a). Roles for menaquinone and the two trimethylamine oxide (TMAO) reductases in TMAO respiration in Salmonella typhimurium: $\mathrm{Mud}\left(\mathrm{Ap}^{\mathrm{r}} \mathrm{lac}\right)$ insertion mutations in men and tor. Journal of Bacteriology 155 , 1147-1155.

Kwan, H. S. \& Barretr, E. L. (1983b). Purification and properties of trimethylamide oxide reductase from Salmonella typhimurium. Journal of Bacteriology 155, 1455-1458.

LAEMMLI, U. K. (1970). Cleavage of structural proteins during the assembly of the head of bacteriophage T4. Nature, London 227, 680-685.

LAM, Y. \& Nicholas, D. J. D. (1969). A nitrate reductase from Micrococcus denitrificans. Biochimica et biophysica acta 178, 225-234.

LeE, J. V., Gibson, D. M. \& Shewan, J. M. (1977). A numerical taxonomic study of some pseudomonas- 
like marine bacteria. Journal of General Microbiology 98, 439-451.

LEVY, M. R., SisSKin, E. E. \& MCCONKey, C. L. (1976). A protease that increases during a period of enzymic and metabolic adjustment in Tetrahymena. Archives of Biochemistry and Biophysics 172, 634-647.

MARTIN, E. L. \& MACLEOD, R. A. (1971). Isolation and chemical composition of the cytoplasmic membrane of a Gram-negative bacterium. Journal of Bacteriology 105, 1160-1167.

McEwan, A. G., Ferguson, S. J. \& Jackson, J. B. (1983). Electron flow to dimethylsulphoxide or trimethylamine- $N$-oxide generates a membrane potential in Rhodopseudomonas capsulata. Archives of Microbiology 136, 300-305.

Merrill. C. R., Goldman, D., Sedman, S. A. \& EBERT, M. H. (1981). Ultrasensitive stain for proteins in polyacrylamide gels shows regional variation in cerebrospinal fluid proteins. Science 211, 1437-1438.

NASSER, Z. M. \& WARD, F. B. (1983). Assay and location of a molybdenum cofactor in strains of Alteromonas putrefaciens. Society for General Microbiology Quarterly 10, M21.

Peterson, G. L. (1977). A simplification of the protein assay method of Lowry et al. which is more generally applicable. Analytical Biochemistry 83, 346-356.

Ringø, E., Stenberg, E. \& Strøm, A. R. (1984). Amino acid and lactate catabolism in trimethylamine oxide respiration of Shewanella putrefaciens NCMB 1735. Applied and Environmental Microbiology 47, 1084-1089.
SaKaguchi, M. \& KawaI, A. (1977). Electron donors and carriers for the reduction of trimethylamine $N$ oxide in Escherichia coli. Bulletin of the Japanese Society of Scientific Fisheries 43, 437-442.

SAKAGUCHI, M. \& KaWAI, A. (1978). Presence of $b$ - and $c$-type cytochromes in the membrane of Escherichia coli induced by trimethylamine $N$-oxide. Bulletin of the Japanese Society of Scientific Fisheries 44, 9991002.

Shimokawa, O. \& Ishimoto, M. (1979). Purification and some properties of inducible tertiary amine- $\mathrm{N}$ oxide reductase from Escherichia coli. Journal of Biochemistry 86, 1709-1717.

Shultz, J. E. \& Weaver, P. F. (1982). Fermentation and anaerobic respiration by Rhodospirillum rubrum and Rhodopseudomonas capsulata. Journal of Bacteriology 149, 181-190.

StenberG, E., Ringø, E. \& Strøm, A. R. (1984). Trimethylamine oxide respiration of Shewanella putrefaciens NCMB 1735: $\mathrm{Na}^{+}$-stimulated anaerobic transport in cells and membrane vesicles. Applied and Environmental Microbiology 47, 1090-1095.

WOOD, A. J. \& BAIRD, E. A. (1943). Reduction of trimethylamine oxide by bacteria. I. The Enterobacteriaceae. Journal of the Fisheries Research Board of Canada 6, 195-207.

Yамамото, I. \& Ishimoto, M. (1977). Anaerobic growth of Escherichia coli on formate by reduction of nitrate, fumarate and trimethylamine $N$-oxide. Zeitschrift für allgemeine Mikrobiologie 17, 235-242. 